\title{
ОТ РЕДАКЦИИ
}

DOI: $10.22363 / 2224-7580-2021-3-6-8$

В центре внимания нашего журнала находятся вопросы развития фундаментальной физики в тесной связи с философией, точнее, с ее центральной частью - метафизикой. В связи с этим уместно напомнить слова членакорреспондента РАН Владимира Васильевича Миронова, недавно безвременно ушедшего из жизни члена нашей редколлегии, декана философского факультета МГУ имени М.В. Ломоносова, который определял метафизику как «предельный вид философского знания». Он писал: «Термин «метафизика» отличается от понятия философии. Это как бы ее теоретическая часть или сердцевина - учение о первоосновах сущего. Не случайно ее иногда называют теоретической философией, противополагая ее практическим разделам» [1. C. 35].

О тесной связи философии (метафизики) с развитием естествознания (фактически с фундаментальной физикой) неоднократно писала членкорреспондент РАН Пиама Павловна Гайденко, член нашей редколлегии со дня основания журнала, также на днях ушедшая из жизни. Именно убежденность в тесной связи философии и науки побудила ее написать прекрасные монографии: «История греческой философии в ее связи с наукой» [2] и «История новоевропейской философии в ее связи с наукой» [3]. Редколлегия журнала намерена всячески способствовать утверждению и развитию взглядов наших ушедших из жизни коллег в отечественном научном сообществе.

Названные прискорбные события заставляют нас еще раз задуматься о состоянии и значении философии, что и определило тематику этого номера журнала. Данный выпуск журнала состоит из трех разделов. Первый раздел «Единство фундаментальной физики и метафизики» содержит статьи, в которых подчеркивается тесная, неразрывная связь «предельного вида философского знания» с исследованиями в области фундаментальной теоретической физики. Показывается, что это особенно важно в настоящий момент, когда в мировой науке сложились условия для очередного пересмотра представлений о физической реальности. Об этом все громче и настойчивее заявляют физики как у нас в стране, так и за рубежом. В разделе содержится три статьи, в том числе С.Н. Жарова и Ю.С. Владимирова, а также перевод на русский язык статьи известного итальянского физика-теоретика К. Ровелли «Физика 
нуждается в философии, а философия - в физике», который уже давно выступает за существенный пересмотр сложившихся представлений о физической картине мира, причем на основе принципов реляционного подхода.

Во второй раздел «Метафизика и теоретическая физика» вошли статьи физиков и философов, в которых обсуждаются актуальные проблемы современной фундаментальной физики с позиций философии. Таковыми являются вопросы построения петлевой квантовой гравитации (статья В.Д. Эрекаева), реляционного осмысления информации (статья А.Л. Круглого), обсуждение идей мировой гармонии, и в частности проявлений золотой пропорции в естествознании (статья О.Б. Балакшина). Несомненный интерес представляет также статья В.Н. Катасонова «Две традиции в отношении актуальной бесконечности».

Третий раздел «Место философии в мировой культуре» также содержит четыре статьи в которых представлен более широкий взгляд на роль научного мышления и философии в мировой культуре.

Обсуждение названных вопросов особенно важно в связи с тем, что в нашей стране в прошлом веке, в эпоху главенства учения диалектического материализма, не подвергалась сомнению важная роль философии в науке. Ныне, когда в стране произошла коренная перестройка идеологии и учение диамата оказалось отвергнутым, отношение к философии в научном сообществе в значительной степени стало негативным, а сама философия постепенно превратилась в историю философской мысли, слабо связанную с решением актуальных проблем современного естествознания.

В связи с этим уместно более внимательно отнестись к мыслям, высказанным в упомянутых выше книгах П.П. Гайденко. Так, в своей книге [3] Пиама Павловна отмечала, что если в античности определяющим было «знание, то в средние века проявляется ярко выраженная тенденция перенести центр тяжести из знания в веру, из разума в волю», то есть в религию. Во второй половине XIX - первой половине XX в. существенное влияние на развитие философии оказала социология (классовая борьба и производственные отношения). Именно на этой почве сформировалось учение марксистско-ленинского диалектического материализма. Естественно встает вопрос: что будет доминантой в философии будущего? Ряд наших коллег склоняется к мысли, что будущей доминантой в философии должна стать фундаментальная физика. Как нам представляется, эта мысль достойна подробного обсуждения не только на страницах нашего журнала, но и в более широком плане.

Завершает выпуск журнала некролог к кончине Пиамы Павловны Гайденко (1934-2021 гг.), ушедшей из жизни 2 июля с.г. после продолжительной болезни. Ее мысли и труды, посвященные развитию философии в неразрывной связи с наукой, чрезвычайно важны для формирования единства этих ключевых разделов мировой культуры.

Ю.С. Владимиров 


\section{Литература}

1. Миронов В.В. Становление и смысл философии как метафизики // Альманах «Метафизика. Век XXI». Вып. 2. М.: БИНОМ. Лаборатория знаний, 2007.

2. Гайденко П.П. История греческой философии в ее связи с наукой. М.: Изд-во «Университетская книга», 2000.

3. Гайденко П.П. История новоевропейской философии в ее связи с наукой. М.: Изд-во «Университетская книга», 2000. 